\title{
BENTUK DAN DAMPAK KEMAMPUAN MEMBERI PENGUATAN DALAM PRAKTIK MENGAJAR MAHASISWA
}

\author{
'Didi Yulistio, ${ }^{2}$ Rio Kurniawan
}

\author{
Universitas Bengkulu
}

\section{Korespondensi: yulistiodidi@unib.ac.id}

\begin{abstract}
Abstrak
Tujuan penelitian ini untuk mengetahui Bentuk dan Dampak dari Kemampuan Memberi Penguatan (reinforcement) dalam Praktik Pengajaran Mikro Mahasiswa Program Sarjana Pendidikan bahasa Indonesia FKIP Universitas Bengkulu. Ruang lingkup penelitian ini mencakup deskripsi (1) jenis penguatan mencakup penguatan verbal dan penguatan nonverbal dan (2) dampat pemberian penguatan sesuai konteks proses pembelajaraan dalam pengembangan karakter peserta didik. Penelitian ini menggunakan metode deskriptif dan pendekatan kualitatif. Pengumpulan data menggunakan teknik pengamatan dan wawancara melalui diskusi terbimbing kepada mahasiswa praktikkan. Sampel penelitian menggunakan teknik purposive sampling, yakni mahasiswa semester 7B (kelompok D) Program Pendidikan Bahasa Indonesia FKIP Universitas Bengkulu yang mengikuti perkuliahan Pengajaran Mikro sebanyak 11 orang. Analisis data secara kualitatif meliputi kegiatan mengamati dan mencatat proses pembelajaran, mengelompokkan data menurut jenis penguatan dan dampak penguatan, mentabulasi data sesuai masalah, menginterpretasi dan evaluasi data serta menarik kesimpulan. Hasil Penelitian dapat dikemukakan bahwa (1) bentuk kemampuan dalam memberi penguatan yang dilakukan mahasiswa meliputi (a) penguatan (reinforcement) verbal berupa kata atau frasa, seperti kata ya, oke, bagus, baik, bisa, boleh, benar, betul, tepat, seratus, baik sekali, sangat bagus, betul sekali, tepat sekali, dan (b) penguatan nonverbal berupa tepuk tangan, tanda tangan mengepal, tangan memberikan jempol, dengan senyuman, mengangguk, menepuk bahu, dan mendekati, yang biasanya dilakukan mengiringi penguatan verbal berupa kata atau frasa yang diucapkan, dan (2) dampak pemberian penguatan sesuai konteks peristiwa berbahasa, mencakup partisipan, pokok pembicaraan, lokasi, dan variasi bahasa, berdampak dalam melahirkan karakter peserta didik, seperti disiplin, mandiri, bertanggung jawab, mengumpulkan tugas tepat waktu, religius, dan nasionalisme yang tinggi.
\end{abstract}

Kata kunci: Kemampuan, Penguatan, Pengajaran Mikro, Verbal.

\section{Abstract}

The purpose of this study was to determine the form and impact of the ability to provide reinforcement (reinforcement) in the Micro Teaching Practice of Indonesian Language Education Undergraduate Program Students, FKIP Bengkulu University. The scope of this research includes a description of (1) types of reinforcement including verbal reinforcement and nonverbal reinforcement and (2) the impact of providing reinforcement according to the context of the learning process in developing the character of students. This study uses a descriptive method and a qualitative approach. Collecting data using observation and interview techniques through guided discussions for students to practice. The research sample 
used a purposive sampling technique, namely students of semester 7B (group D) of the Indonesian Language Education Program FKIP Bengkulu University who attended the Micro Teaching lecture as many as 11 people. Qualitative data analysis includes observing and recording the learning process, classifying data according to the type of reinforcement and the impact of reinforcement, tabulating data according to problems, interpreting and evaluating data and drawing conclusions. The results of the study can be stated that (1) the form of ability in providing reinforcement by students includes (a) verbal reinforcement in the form of words or phrases, such as the words yes, okay, good, good, can, may, right, right, right, one hundred, very good, very good, very right, very right, and (b) nonverbal reinforcement in the form of clapping, clenching signatures, hand giving thumbs up, with a smile, nodding, patting the shoulder, and approaching, which is usually done accompanying verbal reinforcement in the form of spoken words or phrases, and (2) the impact of providing reinforcement according to the context of language events, including participants, subject matter, location, and language variations, having an impact on giving birth to the character of students, such as discipline, independence, responsibility, collecting assignments on time, religious, and high nationalism.

Keywords: Ability, Reinforcement, Micro Teaching, Verbal Reinforcement.

\section{PENDAHULUAN}

Adanya tuntutan capaian kualitas pendidik dalam UU nomor 14 tahun 2005 tentang profesionalitas guru mengisyaratkan bahwa guru profesional harus memiliki lebih awal kompetensi pedagogi dan kompetensi akademik disamping kompetensi kepribadian dan sosial yang diharapkan terbentuk seiring berjalannya proses pengelolaan pembelajaran oleh setiap guru sebagai karakter pendidik yang berkualitas. Hal ini harus dijawab oleh lembaga seperti LPTK atau FKIP sebagai lembaga pencetak guru berkualitas. Artinya, mahasiswa calon guru termasuk guru bahasa Indonesia hasil penggodogan di Lembaga Pendidikan Tenaga Kependidikan harus siap secara mandiri dan mampu memilih dan menyajikan materi dalam proses pembelajaran sebagai syarat pendidik berkompetensi. Dengan kata lain, mahasiswa calon guru bahasa Indonesia harus mengerti hal apa yang akan diajarkan dan cara mengajarkannya. Cooper (dalam Satori, 2009) menegaskan bahwa kemampuan dasar profesi guru ini, berkenaan dengan pemilikan ilmu mengajar, pemilikan kemampuan bidang ilmu yang diajakan, pemilikan keterampilan menyajikan materi pelajaran yang sesuai secara pedagogi, akademik, dan memiliki sikap sosial serta kepribadian yang tepat relevan dengan kebutuhan diri sendiri, orang lain, dan lembaga tempat bekerja. Pembelajaran merupakan suatu sistem, yang terdiri atas berbagai komponen yang saling berhubungan satu dengan yang lain. Komponen tersebut meliputi tujuan, materi, metode, pendekatan, model, dan evaluasi. Komponen pembelajaran tersebut harus diperhatikan oleh guru dalam memilih dan menyajikan materi pembelajaran (Rusman, Kurniawan, dan Riyana, 2011:15). Komponen sistem pembelajaran ini dapat diartikan sebagai upaya sistematik dan sengaja untuk menciptakan kegiatan interaksi edukatif antara dua pihak, yaitu peserta didik dan pendidik (fasilitator pembelajaran) yang mengelola proses pembelajaran. Pengelolaan proses pembelajaran perlu memperhatikan keterampilan dasar mengajar yang terimplementasi secara baik dan berdaya guna.

Mahasiswa praktikan (calon guru bahasa Indonesia) perlu menguasai delapan keterampilan dasar mengajar, mencakup keterampilan (1) membuka dan menutup 
pelajaran; (2) menjelaskan; (3) mengadakan variasi; (4) memberikan penguatan; (5) bertanya; (6) mengelola kelas; (7) mengajar perorangan \& kelompok kecil; (8) membimbing diskusi kelompok kecil (Barnawi dan Arifin, 2015). Hal tersebut penting dilakukan agar proses pembelajaran yang dikelola guru bahasa Indonesia menimbulkan kegairahan dan menyenangkan peserta didik (salah satunya keterampilan memberi penguatan) menjadi dasar guru bahasa Indonesia dalam menyampaikan materi pembelajaran secara berhasil. Pembelajaran yang berhasil, yakni pembelajaran yang mampu mengaktifkan proses dan membelajarkan peserta didik, seperti mampu menyelesaikan permasalahan yang dihadapi secara cepat dan tepat, melahirkan keterampilan berpikir kritis, kreatif, kolaboratif, dan komunikatif serta memahami isi materi pembelajaran secara mendalam hingga menjadikannya sebagai pengalaman belajar. Beberapa aspek kemampuan dasar mengajar ini harus digunakan guru dalam proses pembelajaran yang dikelolanya sejak awal hingga akhir pembelajaran. Hal ini penting untuk tujuan menciptakan proses dan hasil pembelajaran yang berkualitas. Sebab, pembelajaran sebagai proses interaksi antara peserta didik dengan lingkungannya agar terjadi perubahan perilaku ke arah yang lebih. Artinya, dalam pembelajaran tugas guru yang paling utama adalah mengkondisikan situasi lingkungan pembelajaran yang benarbenar membelajarkan agar menunjang terjadinya perubahan perilaku bagi peserta didik (Kunandar, 2007: 287).

Dengan implementasi delapan keterampilan dasar mengajar secara baik dalam pembelajaran bahasa Indonesia akan menggerakkan peserta didik untuk cepat menguasai pencapaian tujuan pembelajaran. Penerapan ini menjadi tugas guru terkait dengan kompetensi pedagogi yang harus dimiliki, yakni guru bahasa Indonesia harus benar-benar menguasai ilmu mengajar, menguasai karekteristik siswa, dan dukungan persiapan atau rencana pelaksanaan pembelajaran yang baik. Hasil pengamatan di sekolah menunjukkan bahwa guru bahasa Indonesia telah cukup baik dalam mengelola keterampilan dasar mengajar ini. Hasil penelitian Rohmayanti (2019: 32) menyimpulkan bahwa berkaitan dengan implementasi keterampilan dasar mengajar khususya dalam pembelajaran kelompok kecil dan perorangan yang dilakukan guru bahasa Indonesia di SMA Negeri 8 kota Bengkulu sudah berhasil dan relevan dengan unsur-unsurnya, seperti menunjukkan keterampilan dalam merencanakan, melaksanakan pembelajaran, dan mengevaluasi serta melakukan pendekatan secara perorangan, khususnya dalam membimbing peserta didik yang mengalami kesulitan.

Hasi pengamatan peneliti terhadap kegiatan praktik pengajaran mikro mahasiswa, bahwa kegiatan praktik mengajar ini masih perlu ditingkatkan sebagai upaya menyiapkan mahasiswa untuk menjadi guru bahasa Indonesia yang berkualitas. Mahasiswa calon guru ini harus memiliki pengalaman mengajar dasar selain pengalaman dalam merancang persiapan mengajar dan mengelola pelaksanaan pembelajaran sebagaimana hasil riset di atas. Oleh karena itu, calon guru bahasa Indonesia ini perlu dibekali praktik menerapkan delapan keterampilan dasar dalam mengajar khususnya dalam memberi penguatan dan fungsi penguatan itu diberikan kepada peserta didik. Proses penerapan keterampilan dasar ini akan terwujud jika secara mandiri mahasiswa mampu menyiapkan rencana pelaksanaan pembelajaran dan pelaksanaan pembelajaran sesuai program pembelajaran yang telah ditetapkan dengan baik. Kemampuan memberi penguatan dalam proses pembelajaran merupakan salah satu bagian dari keterampilan mengajar dasar yang harus dipersiapkan secara wajar dan maksimal. Sehingga mahasiswa praktikan memahami untuk 
kebutuhan apa penguatan itu diberikan dan bahkan dalam konteks yang bagaimana sehingga perlu diberikan penguatan dalam proses pembelajaran. Secara umum, penelitian ini akan mendeskripsikan bentuk dan dampak kemampuan memberi penguatan (Reinforcement) dalam praktik pengajaran mikro mahasiswa.

Tugas pertama seorang guru dalam pembelajaran, yakni mendidik sedangkan yang kedua adalah mengajar. Untuk melaksanakan tugas mengajar maka seorang guru tidak hanya perlu menguasai materi tetapi juga harus memiliki kemampuan dasar mengajarkannya. Seorang Pendidik harus mampu mempraktikkan secara baik ilmu mengajarnya, seperti ilmu mengajar dasar memberikan penguatan peserta didik, agar tertarik, merasa senang, dan termotivasi dalam belajarnya. Hakikat dan jenis Penguatan (Reinforcement). Penguatan merupakan suatu pemberian respon dari adanya stimulus yang dilakukan (perilaku dalam proses pembelajaran) peserta didik yang berkemungkinan dapat mengakibatkan berulangnya kembali suatu tingkah laku tersebut khususnya jika berdampak sebagai penguatan positif. Sebagaimana dikemukakan Sabri (2005: 85) dan Mulyasa (2009: 22) sama-sama menguraikan bahwa penguatan yaitu segala bentuk respon guru sebagai upaya modifikasi tingkah laku siswa, yang bertujuan untuk meningkatkan perhatian siswa terhadap proses pembelajaran yang sedang berlangsung dan materi pelajaran yang sedang dibahas, meningkatkan motivasi dan minat belajar siswa, meningkatkan pasrtisipasi siswa dalam pembelajaran dan mengarahkan kepada perilaku yang produktif. Selanjutnya, Helmiati (2013:74) menegaskan bahwa penguatan dalam kelas dapat mempengaruhi sikap positif siswa dalam proses pembelajaran, seperti menumbuhkan rasa percaya diri, meningkatkan motivasi, minat, dan perhatian siswa terhadap proses dan hasil pembelajaran, membangkitkan dan memelihara iklim belajar yang kondusif sehingga siswa dapat belajar secara optimal.

Berdasarkan makna penguatan di atas dapat dikemukakan bahwa penguatan (reinforcement) merupakan suatu tindakan yang dilakukan pendidik (guru) baik berbentuk verbal atau nonverbal untuk memberikan respon terhadap tindakan belajar peserta didik dengan tujuan untuk meningkatkan motivasi dan perhatian dalam proses pembelajaran secara optimal, kreatif, dan produktif. Oleh karena itu, tujuan dari pemberian penguatan adalah untuk (a) meningkatkan perhatian dan motivasi belajar siswa, (b) memudahkan siswa dalam memahami materi pembelajaran, (c) mengontrol dan mengubah sikap suka menggangu menjadi tingkah laku belajar yang produktif, (d) mengarahkan kepada cara berpikir yang baik dan mengembangkan diri sendiri dalam belajar, dan (e) mengkoordinasi tingkah laku negatif dan mengarahkan peserta didik kepada perilaku yang lebih positif agar optimal dalam belajar (Suwarna, 2006; dan Alma, 2008: 30).

Pemberian penguatan dalam proses pembelajaran bahasa Indonesia dapat berbentuk (a) penguatan verbal atau (b) penguatan nonverbal. Darmadi (2010:2) menegaskan bahwa penguatan verbal merupakan penghargaan yang dinyatakan dengan lisan. Penguatan verbal yang diberikan oleh guru kepada siswa dapat dinyatakan dengan menggunakan kata-kata atau kalimat. Penguatan berupa kata-kata, seperti ucapan bagus, ya, tepat, betul, bagus sekali, benar sekali, luar biasa, dan sebagainya. Penguatan berupa kalimat, seperti Pekerjaanmu sudah bagus, buatanmu bagus sekali, caramu memberi penjelasan bagus sekali dan lain sebagainya. Helmiati (2013) mempertegas bahwa penguatan verbal dapat berupa kata pujian, dukungan, pengkuan, dorongan untuk menguatkan perilaku dan penampilan peserta didik. Penguatan ini dapat berupa kata atau kalimat, seperti benar, bagus, hebat, pintar, ya, tepat sekali dan ya, seratus untuk kamu, dan seterusnya. Dalam upaya meningkatan 
kualitas proses dan hasil pembelajaran, guru selain menggunakan penguatan verbal juga dapat menggunakan penguatan nonverbal. Penguatan nonverbal yakni semua bentuk perilaku selain berupa ujaran atau bahasa yang digunakan untuk tujuan memberikan motivasi positif. Usman (2005) dan Helmiati (2013) mendeskripsikan penguatan nonverbal atas (a) penguatan dengan gerak isyarat; mimik dan gerakan badan, (b) penguatan dengan mendekati siswa, (c) penguatan dengan sentuhan (contact), (d) penguatan dengan memberikan kegiatan yang menyenangkan atau disenangi siswa, (e) penguatan dengan simbol atau benda seperti kartu bergambar, lencana, dan lainnya, dan (f) penguatan untuk respon jawaban sebagaian yang benar dengan penguatan tak penuh (parsial), seperti " ya, sedikit lagi."

Namun, dari beberapa jenis penguatan yang digunakan guru dalam proses pembelajaran bahwa prinsip dari penggunaan kedua penguatan tersebut harus dipahami dalam rangka memberikan dorongan peserta didik untuk aktif dan kreatif serta produktif memcapai isi dan makna pembelajaran. Oleh karena itu, penguatan yang diberikan harus berdampak efektif karena sesuai secara teknis, tepat waktu, dan tepat sasaran siapa yang diberi penguatan. Selain itu, guru harus dapat menyesuaikan dengan situasi dan kondisi penguatan itu diberikan, kebutuhan serta usia peserta didiknya. Dengan kata lain, penguatan akan berdampak positif mengubah karakter peserta didik jika diberikan dengan penuh kehangatan, menyenangkan, dan semangat membelajarkan serta bermakna bagi peserta didik untuk mencapai prestasi dalam pembelajarannya.

Dampak dari penggunaan penguatan dalam proses pembelajaran bahasa Indonesia yang dikelola guru bahasa Indonesia akan terpantau secara konteks pembicaraan atau proses peristiwa berbahasa. Dell Hymes (dalam Pateda, 1987:19-24) menguraikan bahwa penggunaan bahasa verbal atau nonverbal dalam suatu peristiwa berbahasa (berkomunikasi) seperti dalam kegiatan memberi penguatan akan melibatkan beberapa komponen terkait, seperti (a) di mana tempat dan kapan waktunya (setting), (b) dengan siapa dengan siapa yang berbicara (partisipan), (c) apa yang dibicarakan (topiknya), (d) untuk tujuan dan fungsi apa, (e) apa pesan dan bentuknya, (f) bagaimana cara penyampaiannya, (g) jalur lisan, isyarat, atau tulis, (h) dengan cara berinteraksi, bertanya atau apa, dan (i) apa ragam bahasa yang yang dipakai; cerita, puisi, dan lainnya. Hal ini merupakan pelibatan konteks peristiwa berbicara yang disebut dengan akronim SPEAKING; Setting (and scene), Participants, Ends (purpose and goal), Act sequences, Key (tone or spirit of act), Instrumentalities, Norms (of interaction anda interpretatio), dan Genres). Konteks peristiwa berbahasa itu akan menentukan atau bahkan berdampak pada siapa yang dikenai pembicaraan tersebut yang secara penguatan positif akan berfungsi sebagai media/sarana pembentukan karakter peserta didik dalam proses pembelajaran bahasa Indonesia. Oleh karena itu, pemberian penguatan yang melibatkan dua aspek besar yakni (a) penguatan verbal yang berupa kata atau bahasa dan (b) penguatan nonverbal yang dapat berupa isyarat, gerakan tangan, mata atau badan perlu diberikan sebagai upaya memotivasi dan memberikan dorong kepada peserta didik untuk lebih aktif dalam proses pembelajaran.

Kegiatan pemberian penguatan diberikan tidak saja dalam proses pembelajaran di kelas formal di sekolah, dari guru untuk peserta didik tetapi yang lebih khusus dan penting terimplementasi, yakni ketika calon guru (mahasiswa praktikan) melakukan kegiatan praktik di depan peserta didik atau dalam proses pembelajaran kecil (micro teaching). Kegiatan praktik pembelajaran ini sangat penting dievaluasi karena sebagai sarana untuk membentuk keterampilan mengajar calon guru. Praktik mengajar di kelas lab micro teaching 
ini melibatkan mahasiswa sebagai praktikan dan dipandu oleh dosen mata kuliah. Dalam penelitian ini kegiatan praktik pengajaran mikro pada mahasiswa Prodi Pendidikan Bahasa Indonesia dilakukan oleh mahasiswa semester VII yang akan melakukan magang II (praktik pembelajaran di sekolah). Upaya praktik pembelajaran kecil ini dilakukan untuk membekali mahasiswa agar siap tampil mengajar ketika praktik di sekolah. Kegiatan dilakukan dengan melatih mahasiswa atau latihan mengajar dengan menerapkan kompetensi pedagogi yakni ilmu mengajar, seperti berlatih mengelola siswa, berlatih menerapkan delapan keterampilan dasar mengajar (membuka dan menutup pelajaran, bertanya, menjelaskan, modeling, demontrasi, membangun kolaborasi, memberi penguatan, memberikan variasi) dan berlatih menyusun dan menerapkan rencana pelaksanaan pembelajaran (RPP) serta mengembangkan perangkat pembelajaran (menyusun RPP, bahan ajar, LKPD, media pembelajaran, dan alat penilaian) sesuai dengan konsep belajar sambil mengajar (learning by teaching) (Suyono dan Hariyanto, 2011: 234).

\section{METODE PENELITIAN}

Penelitian ini menggunakan pendekatan kualitatif dengan metode deskriptif. Secara kuantitatif bahwa penelitian ini menggunakan data berupa fakta dan hasil perilaku tindakan atau perbuatan pembelajaran dalam analisisnya.Secara deskriptif bahwa analisis data dilakukan dengan mengemukakan fakta-fakta atau bukti kualifikasi yang dapat digeneralisasi. Metode deskriptif digunakan untuk mendeskripsikan bentuk dan dampak kemampuan memberi penguatan dalam proses pembelajaran yang dilakukan mahasiswa dalam praktik pengajaran mikro. Kegiatan praktik pengajaran mikro dilakukan pada bulan September dan Oktober 2020 atau semester ganjil 2019/2020 dengan sumber data mahasiswa Pendidikan Bahasa Indonesia FKIP Universitas Bengkulu kelas 7B (kelompok D) sebanyak 12 orang. Pengumpulan data menggunakan pedoman pengamatan dan teknik FGD untuk mendeskripsikan aspek (1) penguatan verbal dan nonverbal, dan (2) dampak perubahan sikap karakter pada proses berbahasa dalam speaking peserta didik. Analisis data dilakukan secara kualitatif (Moleong, 2011:330) dengan langkah-langkah (1) mengamati dan mencatat proses pembelajaran dalam memberi penguatan, (2) mengelompokkan data berdasarkan permasalah berkaitan dengan bentuk dan dampak penguatan, (3) mentabulasikan data sesuai permasalahan penelitian, (4) menganalisis, mengevaluasi, dan menginterpretasi data sesuai bentuk dan dampak penguatan pada pembentukan karakter peserta didik, (5) menarik simpulan hasil pemberian penguatan.

\section{HASIL PENELITIAN}

Bentuk Penguatan

Deskripsi bentuk pemberian penguatan dalam proses pembelajaran yakni penguatan verbal berupa kata atau frasa dan penguatan nonverbal berupa tindakan atau gerakan anggota badan yang dilakukan guru bahasa Indonesia dalam proses pembelajaran untuk menyatakan setuju atau menrespon jawaban peserta didik. Deskripsi hasil pemberian penguatan verbal dan nonverbal dimaksud sebagaimana tabel berikut ini.

\begin{tabular}{|c|l|l|}
\hline NO & $\begin{array}{c}\text { PENGUATAN VERBAL } \\
\text { (Kata, Frasa) }\end{array}$ & $\begin{array}{c}\text { PENGUATAN NONVERBAL } \\
\text { (Tindakan atau Gerakan Anggota badan) }\end{array}$ \\
\hline 1. & Ya, Iya, Iya bagus & Mengepal \\
\hline 2 & Baik, baik sekali & Memberikan tanda telunjuk \\
\hline
\end{tabular}




\begin{tabular}{|l|l|l|}
\hline 3 & Bagus, sangat bagus & Tepuk tangan \\
\hline 4 & Oke, bisa, boleb & Mendekati peserta didik yang menjawab \\
\hline 5 & Benar, ya benar & Memberi tanda dengan senyum \\
\hline 6 & Betul, betul sekali & Menepuk bahu peserta didik \\
\hline 7 & Tepat, tepat sekali & Mengangguk-angguk \\
\hline 8 & Ya seratus, hebat & Memberi tanda jempol \\
\hline
\end{tabular}

Berdasarkan tabel di atas bahwa pemberian penguatan positif secara verbal, yakni penguatan yang dimunculkan guru berupa kata atau frasa dan penguatan nonverbal yakni penguatan yang diberikan guru berupa perilaku tindakan atau gerakan anggota badan dan pancainfra secara umum dimaksudkan untuk menyatakan setuju atau menyetujui jawaban peserta didik walaupun kemungkinan jawabannya belum sempurna. Penguatan dalam bentuk verbal dan nonverbal di atas diberikan dalam proses pembelajaran secara langsung dalam konteks pembicaraan antara guru dengan peserta didik baik secara individual, kelompok, dan klasikal ketika sedang membahas pokok bahasan materi pembelajaran bahasa Indonesia. Artinya, bentuk-bentuk penguatan itu digunakan guru ketika sedang mengelola proses pembelajaran bahasa Indonesia. Khususnya dalam memberikan respon terhadap aktivitas peserta didik seperti dalam memberikan jawaban, menjelaskan hasil diskusi, dan menanggapi jawaban temannya. Karena, kemampuannya memberi penjelasan atau menanggapi itu, guru memberikan perhatian sebagai penghargaan secara verbal dengan kata atau frasa dan secara nonverbal berupa gerakan tangan atau senyuman yang bersifat positif sehingga tetap memotivasi peserta didik dalam pembelajaran.

Contoh kegiatan pembelajaran ini seperti pada percakapan guru bahasa Indonesia dengan peserta didik yang sedang mengajar materi pokok bahasan unsur Instrinsik menulis teks cerpen, berikut ini.

Guru : Selamat siang, anak-anak!!

Siswa : Selamat siang Bu (suara siswa serentak terdengar bersama).

Guru : Hari ini kita akan belajar Struktur teks Cerpen.

Guru : Siapa yang dapat menjelaskan struktur teks cerpen?

Siswa1 : Saya Bu.(Abdullah merespon sambil mengacungkan jari telunjuknya).

Guru : Ya, silakan kamu Abdullah (Ibu Ani berjalan mendekati Abdullah)

Siswa1 : Struktur teks cerpen mencakup tiga unsur yakni orientasi, komplikasi, dan resolusi, bu.

Guru : Ya, betul sekali (bu Ani membenarkan jawaban Abdullah sambil Menepuk babunya).

Dalam memberikan penguatan, Ibu Ani, guru bahasa Indonesia menggunakan penguatan verbal berupa kata dan frasa "Ya, Betul Sekali", dan penguatan nonverbal yakni dengan menepuk bahu Abdullah karena bu Ani sudah dari awal memberi pertanyaan telah memposisikan dirinya berada di sebelah siswanya itu. Oleh karena itu, dalam proses pembelajaran ini langsung terjadi pemberian penguatan dua jenis, yakni penguatan verbal dan nonverbal. Kedua penguatan itu bersifat positif dan dimaksudkan untuk memberikan penghargaan dan motivasi pada peserta didik (tidak hanya Abdullah) karena telah menjawab secara benar pertanyaan yang diajukan serta agar semangat dalam belajarnya.

Beberapa bentuk penguatan verbal dan penguatan nonverbal yang digunakan guru praktikan (mahasiswa) dalam proses pembelajaran bahasa Indonesia yakni (a) Penguatan verbal berupa kata "ya, iya, bagus, baik, oke, bisa, boleh." Penguatan verbal 
dengan kata " $y a$, iya" intinya sama untuk memberikan penghargaan atas jawaban atau laporan hasil diskusi tetapi belum lengkap kebenara jawabannnya. Digunakannya kata tersebut untuk menghindari penguatan negatif. Sedangkan penguatan dengan kata bagus, baik, oke, bisa, dan boleh juga dimaksudkan untuk pembenaran jawaban yang disampaikan peserta didik namun jawaban tersebut kemungkinan belum sempurna. Oleh karena itu, biasanya permintaan jawaban yang lebih lengkap atas pertanyaan tersebut masih diminta dari siswa lainnya. Penguatan dengan kata tersebut diberikan sebagai bentuk penghargaan kepada siswa yang telah menjawab dengan menghindari respon guru dengan penguatan yang bersifat negatif seperti kurang lengkap, belum benar, dan lainnya, (b) Penguatan verbal berupa kata "benar, betul, tepat, seratus, hebat." Penggunaan bentuk penguatan verbal dengan kata "benar, betul, tepat, seratus, hebat", menunjukkan guru sudah sangat puas atas usaha siswanya dalam memberikan jawaban pertanyaan atau tampilan penjelasan hasil diskusi yang disampaikan secara individual, kelompok atau klasikal. Penggunaan penguatan verbal ini biasanya diikuti dengan penguatan nonverbal apabila guru dalam kondisi membimbing siswa dalam kelompok-kelompok belajar dan perorangan, (c) Penguatan verbal berupa frasa "baik sekali, sangat bagus, betul sekali, tepat sekali." Penggunaan penguatan dengan frasa verbal seperti "baik sekali, sangat bagus, betul sekali, dan tepat sekali" merupakan pemberian penghargaan dan motivasi yang lebih lengkap sebagai respon jawaban benar atau penjelasan hasil diskusi dan lainnya yang disampaikan peserta didik. Penggunaan frasa ini menunjukkan kepuasan guru atas aktivitas siswanya yang lebih baik dari penggunaan kata baik, tepat dan sebagainya, (d) Penguatan verbal berupa frasa "ya, seratus, seratus buat..." Penggunaan penguatan verbal berupa frasa "ya seratus, seratus buat Abdullah.." menunjukkan bahwa jawaban yang disampaikan siswa sudah lengkap dan sesuai dengan yang diminta sehingga guru secara spontan langsung menyatakan kebenaran jawabannya itu dengan nilai sempurna yakni seratus, baik dengan mengucapkan nama yang menjawab atau pun tidak diucapkan.

Penguatan nonverbal dilakukan seperti (a) Penguatan nonverbal berupa pandangan mata terbelalak, tersenyum, dan mengangguk. Penggunaan penguatan nonverbal biasanya mengiringi penguatan verbal. Penguatan seperti pandangan mata terbelalak dan tersenyum atau menggangguk-angguk sebagai tanda bahwa informasi baik jawaban individu atau kelompok sudah lengkap dan benar. Sebagai bentuk motivasi atau penghargaan digunakan anggukan tanda setuju atau tanda pembenaran jawabannya, (b) Penguatan nonverbal berupa acungan telunjuk dengan tangan mengepal. Penguatan nonverbal berupa acungan telunjuk dengan tangan mengepal biasanya menyertai penguatan verbal seperti oke, baik, yang menyatakan kebenaran jawaban tetapi perlu lebih lengkap lagi. Oleh karena itu, biasanya guru masih meminta siswa lain untuk menyampaikan pendapat atau jawabannya secara lengkap dengan kata "Oke, siapa yang bisa melengkapi?" sambil tangannya mengepal dan mengacungkan telunjuknya. Paling tidak sebagai pelengkap diperlukan satu atau dua jawaban dari siswa lainnya, (c) Penguatan nonverbal berupa pemberian jempol dengan tangan mengepal. Penggunaan penguatan nonverbal dengan tangan mengepal dan memberi jempol menunjukkan bahwa informasi berupa jawaban atau penyampaian hasil diskusi secara individu atau kelompok yang dilakukan siswa sudah lengkap dan benar. Oleh karena itu, biasanya penguatan itu dilengkapi dengan kata oke bagus, benar. Sebagai bentuk penghargaan kepada siswa bahwa jawabannya sudah sangat benar, (d) Penguatan nonverbal berupa tepuk tangan. Pemberian penguatan nonverbal berupa tepuk tangan biasanya diberikan kepada kelompok yang telah menyampaikan hasil 
diskusi secara benar sehingga guru memberi tepuk tangan dengan meminta siswa lainnya juga untuk memberikan tepuk tangan bersama atas keberhasilan tersebut. Biasanya hal itu diikuti dengan penguatan verbal dengan kata baik sekali, beri tepuk tangan..." dan (e) Penguatan nonverbal berupa tepukan bahu dengan mendekati peserta didik. Penggunaan penguatan nonverbal berupa tepukan bahu biasanya dilakukan setelah guru menanyakan sesuatu kepada siswa secara kelompok atau individu dan saat bertanya guru sambil berjalan mendekati siswanya. Hal ini dilakukan untuk menguatkan kebenaran jawaban dan memotivasi siswa secara individu bahwa siswa yang telah menjawab benar memang bagus atau dimaksudkan guru untuk memberikan dorongan kepada siswa tersebut secara individu agar lebih semangat lagi dalam belajarnya. Penguatan itu juga diikuti dengan bentuk verbal seperti kata ya, benar sekali (sambil mendekati dan menepuk bahu siswanya).

\section{Dampak Pemberian Penguatan}

Dekripsi dampak pemberian penguatan dalam proses pembelajaran bahasa Indonesia pada praktik pengajaran mikro sesuai konteks peristiwa berbahasa mampu membentuk sikap atau karakter peserta didik secara lebih baik. Khususnya, bermanfaat dalam memotivasi semangat belajar, membuat lebih percaya diri dan berani dalam menyatakan pikiran dan pendapat, dan membuat lebih yakin pada kemampuan diri sendiri serta merasa diperhatikan. Beberapa dampak dari bentuk penguatan yang diberikan sebagaimana tabel berikut ini.

\begin{tabular}{|c|l|l|}
\hline NO & JENIS PENGUATAN & \multicolumn{1}{|c|}{ DAMPAK PENGUATAN } \\
\hline 1. & Ya, baik, bagus, benar, oke & Memotivasi semangat belajar \\
\hline 2. & $\begin{array}{l}\text { Tepat, seratus, bebat, bisa, } \\
\text { boleh. }\end{array}$ & Membuat semakin percaya diri \\
\hline 3. & $\begin{array}{l}\text { Mendekati dan Menepuk, bahu } \\
\text { siswa tanda jawaban benar }\end{array}$ & $\begin{array}{l}\text { Membuat semakin percaya diri dan merasa lebih } \\
\text { diperbatik.an. }\end{array}$ \\
\hline 4. & $\begin{array}{l}\text { Betul sekali, tepat sekali, ya } \\
\text { oke, sangat bagus }\end{array}$ & $\begin{array}{l}\text { Senang dan membuat lebih nyakin pada } \\
\text { kemampuan sendiri }\end{array}$ \\
\hline 5 & $\begin{array}{l}\text { Mengepalkan tangan, memberi } \\
\text { tanda jempol }\end{array}$ & $\begin{array}{l}\text { Membuat semangat dan berani memberikan } \\
\text { jawaban karena yakin benar. }\end{array}$ \\
\hline 6 & $\begin{array}{l}\text { Senyum, tertawa setuju, } \\
\text { menggangguk }\end{array}$ & $\begin{array}{l}\text { Membuat semakin bergairah dalam belajar karena } \\
\text { merasa terbimbing dan tidak terlalu "streng" }\end{array}$ \\
\hline
\end{tabular}

Beberapa dampak positif dari pemberian penguatan baik melalui penggunaan gerakan (nonverbal) maupun penggunaan kata-kata (verbal) secara khusus berampak bagi peserta didik dalam memotivasi dan menguatkan rasa percaya dirinya dalam proses pembelajaran karana stimulus yang diberikan guru membuat peserta didik merasa lebih diperhatikan dan dihargai pendapat dan jawabannya.

Dampak pemberian penguatan sesuai konteks peristiwa bahasa yang dikemukakan Hymes (1972) yang dinyatakan dalam akronim SPEAKING dapat dinyatakan secara sederhana dalam empat unsur yang mencakup siapa partisipannya, apa pokok pembicaraannya, dimana lokasinya, dan bagaimana variasi bahasa yang digunakan (Pateda, 1987:19-24). Deskripsi spesifik konteks peristiwa berbahasa berupa penguatan positif terhadap peserta didik dalam proses pembelajaran tersebut sebagaimana peristiwa ujaran sebagai berikut ini. 
a. Partisipan

: Guru bahasa Indonesia dan Peserta Didik (sebagai Pembicara/pengajar dan sebagai pendengar/pembelajar).

1) Guru Tbu Ani, :Apa yang dimaksud amanat dalam cerpen?

2) Peserta didik 'Rudi, :Pesan yang disampaikan penulis dalam cerpen, bu.

3) Guru 'Tbu Ani' :ya, betul sekali.

b. Pokok Pembicaraan : Materi Pembelajaran (bersifat argumentasi)

1) Pokok bahasan : Unsur Instrinsik dalam Cerpen (Unsur Amanat).

c. Lokasi

1) Tempat pembelajaran

d. Variasi Bahasa

: Proses Pembelajaran di kelas formal.

: Di kelas XI-1 SMAN Kota.

: Menggunakan bentuk bahasa lisan formal berupa pemberian penguatan dengan kata, frasa dan perilaku

atau

gerakan anggota badan.

1) Bentuk Bahasa : Bahasa Lisan formal argumentatifyang digunakan dalam

Proses pembelajaran di kelas oleh guru Tbu Ani' berupa

Kata "ya, betul sekali," sebagai penguatan atas jawaban

Benar yang disampaikan Rudi.

e. Dampak

: Rudi merasa senang dan menjadi lebih percaya diri dalam

berpendapat karena jawabannya mendapat respon dari Ibu

Ani yang menyatakan betul sekali.

Penggunaan kata atau frasa 'ya, betul sekali' merupakan penguatan yang digunakan guru (Ibu Ani) sebagai respon atas jawaban benar yang disampaikan Rudi. Penguatan tersebut berdampak positif dalam perkembangan sikapnya menjadi lebih percaya diri yang mempengaruhi karakternya hingga menjadi bertanggung jawab.

Dampak pemberian penguatan pada perubahan sikap peserta didik bervariasi bergantung pada daya penerimaannya dan kekuatan sentuhan rasa pada dirinya. Dampak perubahan pada sikap yang berkaitan dengan karakter seperti perubahan pada sikap disiplin, tanggung jawab, kecepatan mengerjakan tugas, keberanian dalam memberi tanggapan dan menjawab pertanyaan, dan meningkatkan rasa kepercayaan diri yang tinggi. Deskripsi dampak pemberian penguatan pada perubahan sikap karakter peserta didik, yakni (a) memotivasi semangat belajar. Penggunaan penguatan seperti kata bagus dengan tindakan atau gerakan anggota tubuh mengepalkan tangan berdampak positif pada sikap peserta didik khususnya dalam memotivasi semangat belajarnya. Pemberian penguatan verbal merupakan penghargaan yang diberikan guru atas capaian menjawab secara benar atau melakukan tindakan yang tepat dalam proses pembelajaran, (b) Merasa lebih diperhatikan. Penggunaan penguatan verbal dengan kata ya, tepat sekali dengan gerakan tangan memberikan jempol akan memberi dampak positif pada peserta didik khususnya dalam sikap santun dan bertindak hati-hati serta lebih percaya diri, Hal ini dapat membuat perilaku peserta didik menjadi lebih bertanggung jawab dan disiplin dalam belajar, (c) Merasa bangga dan senang. Penggunaan kata bebat dengan diiringi tidakan guru mengajak murid lain untuk memberikan tepuk tangan sebagai tanda keberhasilan secara individu atau kelompok dalam proses pembelajaran berdampak positif pada diri peserta didik, khususnya rasa senang dan bangga akan keberhasilannya. Dampak ini bagi anak yang sudah dewasa akan menjadi pemicu positif dalam semangat belajarnya. Karena dalam kegiatan lain mereka harus lebih hati-hati dan tidak boleh 
sembarangan. Dampak positif bagi peserta didik menjadi lebih bertanggung jawab dan santu dalam proses pembelarannya, (d) Merasa lebih percaya diri. Sikap lebih percaya diri pada peserta didik perlu ditanamkan melalui penggunaan penguatan dengan kata, frasa yang secara verbal memicu keyakinannya dalam belajar hingga menjadi lebih baik. Penguatan nonverbal berupa senyuman guru pun akan menggugah semangat dan percaya dirinya karena merasa diperhatikan. Kepercayaan diri peserta didik yang tertananm secara baik akan mempengaruhi sikap karakter mulia dan tumbuh menjadi lebih disiplin dan tepat waktu dalam setiap proses pembelajaran yang dikelola guru bahasa Indonesia, (e) Merasa lebih yakin pada kemampuan diri sendiri. Penguatan yang diberikan guru terhadap jawaban salah dengan tidak mematikan kreativitasnya menggunakan kata verbal atau gerakan nonverbal sebagai penguatan yang bersifat negatif akan dapat menumbuhkan keyakinan akan kemampuan dirinya untuk selalu mencoba memberikan jawaban ketika guru bertanya. Keyakinan ini akan mengantarkan peserta didik untuk menjadi lebih serius dalam belajar dan dapat tumbuh menjadi lebih mandiri dan bertanggung jawab, (f) Membuat lebih berani dalam menjawab pertanyaan. Dukungan moral berupa kata atau gerakan anggota tubuh guru yang mengisyaratakan penghargaan terhadap jawaban yang diberikan peserta didik membuat mereka semakin berusaha untuk menjawab lebih baik dan berana berpendapat. Hal ini merupaka sikap karakter yang bertanggung jawab dan percaya kepada diri sendiri, (g) Membuat semakin bergairah dalam belajar. Menguatkan dengan kata-kata verbal sebagai bentuk penghargaan pada jawaban yang belum benar atau tepat akan berdampak positif pada diri peserta didik. Sebab, mereka tidak merasa dilecehkan di depan temannya. Walaupun jawabannya belum benar mereka merasa nyaman karena tidak merasa dipermalukan guru. Dampak penguatan ini membuat sebagian besar peserta didik menjadi lebih berhati-hati dalam menjawab pertanyaan dan semakin bergairah dalam belajar agar ketika akan memberikan jawaban berikut ini tidak salah lagi dan justru mendapatkan penghargaan yang semakin jelas, dan (h) Merasa lebih yakin dalam berpendapat. Untuk melahirkan keyakinan dalam berpendapat pada diri peserta didik salah satunya dapat dilakukan guru dengan memberikan penguatan verbal berupa kata, frasa yang bermakna positif. Kata-kata seperti "bagus, tepat, benar" merupakan kata penguatan sikap yang membuat siswa lebih yakin akan kemampuannya dalam berpendapat atau ketika menjawab pertanyaan. Keyakinan ini akan membuat sikap karakter mulai siswa tumbuh menjadi anak yang mandiri, bertanggung jawab atau disiplin, dan lainnya.

\section{PEMBAHASAN}

Berdasarkan hasil penelitian kemampuan memberi penguatan dalam proses pembelajaran bahasa Indonesia para praktik pengajaran mikro mahasiswa semester VII-B Prodi S-1 Pendidikan Bahasa Indonesia FKIP Universitas Bengkulu bahwa dapat dideskripsikan penguatan dalam bentuk verbal berupa kata, frasa atau kalimat seperti ya, oke, benar, betul, bagus, tepat, seratus, hebat, benar sekali, betul sekali, tepat sekali, hebat sekali, bisa, boleh, dan penguatan nonverbal berupa perilaku tindakan atau gerakan anggota badan dan pancaindra seperti mengacungkan jari telunjuk sambil mengatakan betul, mengepalkan tangan tanda setuju, memberi tanda jempol kepada peserta didik yang menjawab benar, tepuk tangan, senyuman, keryitan dahi disertai mata membelalak tanda 
sepakat, dan anggukan kepala tanda setuju. Hal ini sesuai dengan pendapat yang disampaikan Helmiati (2013:74-75) bahwa penggunaan penguatan verbal sebagai respon yang berupa kata-kata, frasa, dan kalimat penghargaan, dukungan, pengakuan, dan dorongan yang dipergunakan untuk tujuan menguatkan tingkah laku dan penampilan peserta didik agar menjadi lebih baik. Disamping itu, penguatan berupa kata yang disertai isyarat gerakan anggota tubuh sebagai bentuk penguatan nonverbal sangat menguatkan secara positif upaya memotivasi belajar peserta didik. Hal ini ditegaskan Usman (2005:81) bahwa penguatan nonverbal terdiri dari penguatan gerak isyarat, dengan pendekatan, sentuhan, dengan kegiatan menyenangkan, dengan simbol dan benda, dan penguatan tak penuh baik pada kelompok atau pun perorangan sangat penting dilakukan guru dalam memacu aktivitas peserta didik dalam proses pembelajaran.

Disisi lain, bahwa dampak pemberian penguatan sesuai konteks proses pembelajaran bahasa Indonesia sangat berperan penting dalam pembentukan sikap karakter mulai bagi peserta didik. Sebab, melalui penguatan positif yang disampaikan guru (dalam beberapa kali proses pembelajaran terhadap seorang peserta didik) walaupun jawabannya belum sempurna akan membangkitkan semangatnya dalam belajar, khususnya tidak patah semangat dalam mencoba menjawab pertanyaan guru ketika proses pembelajaran berlangsung. Untuk itu, guru perlu menghindari penguatan negatif yang menggunakan kata, frasa yang secara verbal kurang bermakna dan dapat menurunkan semangat belajar peserta didik. Guru perlu menghindari kata seperti kurang tepat, salah, tidak benar ketika merespon jawaban salah yang diberikan peserta didik. Dalam hal ini Pateda (1987) mengungkapkan bahwa penguatan ini tidak bedanya dengan informasi pesan dari pembicara kepada pendengar atau audien, yang selalu diberikan secara verbal melalui kata-kata atau frasa dan diikuti dengan gerakan motorik anggota badan (bentuk nonverbal) yang dalam ilmu bahasa dinamakan gejala paralinguistik. Kepiawaian memilih kata, frasa yang digunakan untuk menguatkan pesan informasi dapat mendorong pendengar lebih bersemangat dalam memahami makna yang bawa pesan tersebut.

Penguatan ini dapat diwadahi dalam konteks peristiwa berbahasa yang dinyatakan Dell Hymes (1972) melalui delapan unsur akronim SPEAKING. Unsur Speaking ini mencakup S (setting and Scene) berkaitan dengan tempat dan waktu serta situasi psikologis seperti apa hal penguatan itu dilakukan, $\mathrm{P}$ (participants) berkaitan dengan siapa pembicara yang berbicara dengan siapa pendengarnya dan audien atau peserta lainnya, $\mathrm{E}$ (ends; purpose and goal) berkaitan dengan apa tujuan peristiwa berbahasanya, A (act sequences) berkaitan dengan bentuk ujaran dan jenis informasi pesan, $\mathrm{K}(\mathrm{key})$ berkaitan dengan cara atau spirit berbahasa; serius, ironi, lucu dan sebagainya, I (instrumentalities) berkaitan dengan jalur atau variasi bahasa yang digunakan, $\mathrm{N}$ (norms) berkaitan dengan konvensi norma, dan G (genres) berkaitan dengan bentuk dan ragam bahasa yang digunakan seperti genre puisi, argumentasi.

Kedelapan unsur tersebut di atas dapat dinyatakan secara lebih padat dalam empat unsur konteks, khususnya untuk membangun pengaruh penggunaan penguatan yang sesuai dengan konteks peristiwa berbahasa dalam proses pembelajaraan bahasa Indonesia, yakni (1) faktor yang berhubungan dengan partisipan dalam pembicaraan yakni guru yang mengajar dengan peserta didik yang sedang belajar dan siswa lain sebagai pendengar atau audien, (2) pokok pembicaraan yakni materi pembelajaran yang bersifat argumentasi formal di kelas, (3) lokasi berbahasa yakni di kelas formal yang menggunakan 
bahasa formal dalam situasi formal yang bertujuan menyampaikan informasi materi pembelajaran dengan pemberian penguatan, dan (4) variasi bahasa yakni berkaitan penggunaan bentuk bahasa verbal dari guru kepada peserta didik dan dampaknya dalam pembentukan karakter. Hasil konteks peristiwa berbahasa antara guru dengan peserta didik bahwa ketika guru memberikan penguatan verbal dan nonverbal dalam pembelajaran berupa kata atau frasa sebagai bentuk penghargaan, pujian, dan dorongan menjadi pemicu semangat dan berdampak positif bagi peserta didik dalam pembelajaran bahasa Indonesia. Dampak tersebut menimbulkan terbangunnya karaker mulia peserta didik seperti menjadi religius, disiplin, mandiri, rajin belajar, cepat menjawab pertanyaan, tepat waktu ketika mengerjakan dan mengumpulkan tugas, serta berani berpendapat dan berjiwa nasionalisme kebangsaan yang tinggi karena semakin percaya diri.

\section{KESIMPULAN}

Berdasarkan hasil penelitian dan pembahasan tentang bentuk dan dampak dari "Kemampuan Memberi Penguatan (Reinforcement) dalam Praktik Pengajaran Mikro Mahasiswa Program Sarjana Pendidikan Bahasa Indonesia FKIP Universitas Bengkulu" dapat disimpulkan bahwa (1) ditemukan bentuk penguatan verbal berupa kata dan frasa dan penguatan nonverbal berupa gerakan anggota tubuh dan pancaindra untuk tujuan memberi dukungan, memotivasi, dan memberi jawaban peserta didik, dan (2) dampak pemberian penguatan dalam proses pembelajaran sesuai konteks peristiwa berbahasa, yang berkaitan dengan siapa partisipannya, apa pokok pembicaaannya, lokasi pembicaraannya, dan variasi ragam bahasa yang digunakan, membentuk atau melahirkan karakter peserta didik berupa sikap disiplin, mandiri, bertanggung jawab, tepat waktu, religius, dan nasionalisme tinggi.

Secara khusus, bentuk dan dampak dari kemampuan memberi penguatan dalam praktik pengajaran mikro mahasiswa, bahwa ditemukan (1) bentuk penguatan yang digunakan dalam proses pembelajaran mencakup (a) penguatan verbal berupa kata atau frasa, seperti kata ya, bagus, baik, oke, bisa, boleh, benar, betul, tepat, seratus, hebat, dan frasa seperti baik sekali, sangat bagus, betul sekali, tepat sekali, sebagai penghargaan, pujian, dan dorongan yang diberikan guru kepada peserta didik, dan (b) penguatan nonverbal berupa tepuk tangan, tanda tangan mengepal, tangan memberikan jempol, dengan senyuman, memberi tanda dengan telunjuk, mengangguk, menepuk bahu, dan mendekati, yang biasanya dilakukan mengiringi penggunaan kata atau frasa yang diucapkan, dan (2) dampak pemberian penguatan dalam proses pembelajaran bahasa Indonesia sesuai konteks peristiwa berbahasa yang berkaitan dengan siap partisipan, pokok pembicaraan, lokasi, dan variasi atau bentuk bahasa yang digunakan berdampak dalam pembentukan sikap peserta didik yang berkaitan dengan karakternya menjadi lebih disiplin, mandiri, bertanggung jawab dan rajin belajar, cepat dalam menjawab pertanyaan, dan tepat waktu dalam mengumpulkan tugas, serta berani berpendapat karena semakin percaya diri dan berjiwa nasionalisme tinggi.

Beberapa saran berkaitan dengan simpulan atas, bahwa (1) bagi calon guru bahasa Indonesia yang akan melaksanakan praktik pembelajaran agar lebih memperhatikan karakter peserta didik dalam memberikan penguatan dan memperhatikan dampak yang ditimbulkan, khususnya pemberian reinforsement yang bersifat negatif, dan (2) bagi pembimbing kegiatan praktik pembelajaran bahwa hasil ini dapat menjadi acuan dalam memberikan pengalaman menerapkan keterampilan dasar mengajar yang baik, khususnya 
dalam memotivasi dan meningkatkan kepercayaan diri praktikkan sehingga mencapai hasil yang berkualitas.

\section{DAFTAR PUSTAKA}

Alma, B. 2008. Guru Profesional Mengusai Metode dan Terampil Mengajar. Bandung: Alfabeta. Barnawi dan M. Arifin. 2015. Micro Teaching: Teori \& Praktik Pengajaran yang Efektif dan Kreatif. Yogyakarta : Ar-Ruzz Media.

Darmadi, H. 2010. Kemampuan Dasar Mengajar. Bandung : Alfabeta.

Djamarah, Syaiful Bahri. 2005. Guru dan Anak Didik. Jakarta: PT RINEKA CIPTA.

Helmiati. 2013. Micro Teaching Melatig Keterampilan Dasar Mengajar. Pekan Baru: Aswajan Pressindo.

Rohmayanti, Ferny, Didi Yulistio, dan Padi Utomo. 2019. "Pelaksanaan Pembelajaran Kelompok Kecil dan Perorangan pada Mata Pelajaran Bahasa Indonesia siswa kelas X di SMA Negeri 8 Kota Bengkulu.” Jurnal Ilmiah KORPUS, Volume III, Nomor I, April 2019.

Rusman, Deni Kurniawan, dan Cepi Riyana. 2011. Pembelajaran Berbasis Teknologi Informasi dan Komunikasi .Jakarta : Rajawali Pers.

Hamalik, U. 2012. Proes Belajar. Jakarta: Bumi Aksara.

Helmiati. 2013. Micro Teaching Melatih Keterampilan Dasar Mengajar. Pekan Baru: Aswajan Pressindo.

Hymes, Dell. 1972. "Model of the Interaction of Language and Social Life" dalam JJ Gumperz dan Dell Hymes, Directions in Sociolinguistics. Holt, Reinhart and Winston Inc. New York.

Kunandar. 2007. Guru Profesional: Implementasi Kurikulum Tingkat Satuan Pendidkan. Jakarta: Rajawali Pers.

Moleong, Lexi J. 2011. Metodologi Penelitian Kualitatif. Bandung: PT Remaja Rosdakarya.

Mulyasa. 2009. Pembelajaran Mikro. Jakarta: Diadit Media.

Pateda, Mansoer. 1987. Sosiolinguistik. Bandung: Angkasa.

Satori. 2013. "Komponen Kompetensi Profesional Guru", Pendidikanku: Informasi Pendidikan Terkini. Http://sdnwonoue.blogspot.com/2013/08.html. Diunduh, 27 April 2015.

Sevilla, Consuelo G, dkk. 1993. Pengantar Metode Penelitian. Terjemahan Alimuddin Tuwu. Jakarta: UI Press.

Suyono dan Hariyanto. 2011. Belajar dan Pembelajaran: Teori dan Konsep Dasar. Bandung: PT. Remaja Rosdakarya.

Usman, M. U. 2005. Menjadi Guru Profesional. Bandung: PT Remaja Rosdakarya. 